\title{
Transcriptional Activation Domain
}

National Cancer Institute

\section{Source}

National Cancer Institute. Transcriptional Activation Domain. NCI Thesaurus. Code C14079.

A DNA-binding domain binds to a specific DNA sequence and a transcriptional activation domain interacts with the basal transcriptional machinery. An association of a transcriptional activation domain with a DNA-binding domain promotes the assembly of RNA polymerase II complexes at the TATA box and increase transcription. ( $\mathrm{NCl}$ ) 